\title{
Anti-establishment coalition governments in Southern Europe: Greece and Italy
}

\author{
Vasiliki Georgiadou \\ Panteion University of Social and Political Sciences, 136 Syngrou Ave. 17671, Athens, \\ Greece. \\ Email: vgeorg@panteion.gr \\ Jenny Mavropoulou \\ Panteion University of Social and Political Sciences, 136 Syngrou Ave. 17671, Athens, \\ Greece. \\ Email: j.mavropoulou@panteion.gr
}

\begin{abstract}
Anti-establishment parties with either a left-wing or a right-wing ideological slant have been entering contemporary European Democracies with sizeable vote shares. During the Great Recession, the Greek and the Italian party system could be perceived as convergent case-studies for the formation and breakthrough of anti-establishment parties. Given the fact that ideologically diverging antiestablishment parties - the Coalition of the Radical Left - Social Unionist Front (SYRIZA) and the Independent Greeks (ANEL) in the Greek case, as well as the Five Star Movement (M5S) and the League in the Italian one - came to power and formed coalition governments, the primary goal of this article is to enquire into supply-side parameters, exploring potential associations along a range of programmatic stances and policy dimensions that effectuated these governing alliances. Using the Comparative Manifesto Project dataset, our findings confirm the existence of expected programmatic differences as well as a converging policymaking basis between the anti-establishment coalition partners of both governing alliances.
\end{abstract}

Keywords: anti-establishment parties, SYRIZA, ANEL, M5S, League, supply-side, issue salience, policy dimensions. 


\section{Introduction}

Entering the post-crisis decade, Southern European countries started to rebound from the multifaceted financial crisis. Regarding the electoral consequences of that period, the framework of the financial crisis could be evaluated as a political opportunity for the radical transformation of voters' electoral behaviour and the rise of electoral volatility (Bosco and Verney 2017; Morlino and Raniolo 2017) accompanied by the fragmentation of party systems and the re-shaping of social cleavages. However, the Greek and the Italian party system could be considered as critical case-studies for the rise of parties that were against the Establishment blazing a trail for the governing alliance among anti-establishment parties from opposing ideological poles along the left-right axis.

Focusing on the Greek case, the January/September 2015 Greek Parliamentary elections pointed out the post-seismic consequences of the 2012 double electoral earthquake confirming the decline of party identifications and the collapse of the two-party system that had prevailed in Greece after 1974, in the post-authoritarian republic. More specifically, SYRIZA, a party derived from the radical left-wing spectrum benefited from the rising popular discontent against austerity measures (Tsakatika 2016) and the collapse of the social democratic PASOK, won the January 2015 Parliamentary election and formed a coalition government with ANEL, a party with a populist radical right-wing slant (Aslanidis and Rovira Kaltwasser 2016), on the basis of their common anti-austerity rhetoric and agenda. A few months later, in the September 2015 Parliamentary elections, SYRIZA renewed the solemn vows with its junior coalition partner despite the fact that the SYRIZA-ANEL coalition was negatively perceived by center-left voters (Rori 2020: 1034)..

Dealing with the Italian case-study, the 2018 General election confirmed the transformation of the Italian party system which had already begun to change since the 2013 General elections judging by the extreme high level of electoral volatility and the electoral breakthrough of the Five Star Movement (Movimento Cinque Stelle/M5S). The outcome of the 2018 General election increased political 
uncertainty; it was accompanied by several rounds of coalition negotiations due to the fact that neither political parties nor party coalitions reached an outright majority. Three months later, the Five Star Movement, an anti-establishment party that was a mixture of left-wing and right-wing claims (Pirro 2018), formed a fragile governing alliance with the populist radical right League (Lega) which collapsed after just 14 months in power. The coalition agreement of the so-called 'yellow-green' coalition government outlined the policymaking goals of the two partners and although it backed away immodarate ideas containing in earlier drafts, the final version of this agreement still reflected the radical orientation of both coalition partners (leraci 2019) ${ }^{1}$.

Our aim here is to enquire into a specific set of factors that are strictly linked with the programmatic stances and policy positions of the SYRIZA-ANEL on the one hand and the M5S-League on the other hand in order to address the governing symbiosis between parties that were divergent in many respects, i.e. ideological, organizational, socio-political. In this paper we center on the election programs which reflect the positions of parties along policymaking dimensions. More specifically, we are interested in investigating if SYRIZA and ANEL managed to bridge their policy differences during their twin coalition government; , our concern focuses on two parties perceived until then as political opponents, the M5S and the League in order to explore potential convergences along a range of stances and policy dimensions that could have effectuated their alliance. The existing literature has been concentrating on the unconventional anti-incumbent opposition of anti-establishment parties and/or on anti-establishment parties that assume government responsibilities together with mainstream parties (Van Spanje 2011). We focus on anti-establishment parties that are partners in anti-establishment ruling coalitions in order to examine whether these parties preserve their antiestablishment identity during their participation in the government. This paper will offer the opportunity to expand the spectrum of the analysis for anti-establishment parties, exploring for

\footnotetext{
${ }^{1}$ For the final text called 'Contract for the Government of Change in Italy' see https://s3-eu-west1.amazonaws.com/associazionerousseau/documenti/contratto governo.pdf).
} 
interactions within and among anti-establishment parties along a range of policy dimensions and look for explanations concerning the parties' impact on each other.

\section{Puzzling over anti-establishment parties}

Over the last four decades, Western European democracies have been undergoing a range of fundamental changes, a fact that has contributed to the profound transformation of party systems (Katz and Mair 1995). The process of party-system transformation followed the erosion of the traditional cleavage structure due to the 'de-freezing' of the long-standing political alignments and the decline of strong relationships between socio-structural variables and party choices (Lipset and Rokkan 1967). Since the 1970s, the consequences of the economic modernization process have led to the emergence of new issues that contributed to the redirection of voting behaviour. At the same time, the shifting of the electorate towards 'new politics' created opportunities for the development of new party families of green/environmental (Poguntke 1992), radical right-wing (Ignazi 1992) and left-libertarian hues (Inglehart 1984). The accelerated transition marked by economic and sociocultural changes, in conjunction with the instability of post-industrial party systems, have been accompanied by the evolutionary presence of anti-establishment parties on the different electoral levels and political stages. During the last decade, the anti-establishment party spectrum has entered into a phase of stability, gradually transforming itself into a notable player in governing competition, a fact directly associated with the onset of the multilevel European crisis: financial, political, sociocultural (Algan et al. 2018).

In the context of a phenomenon that was described as 'decline of party democracy', political scientists in the 1990s used to thematize issues of political protest and anti-party sentiments. At that time, Mudde aptly pointed out that despite citizens' critique on parties, voters with anti-party sentiments 'still voted for parties', choosing A.O. Hirschman's 'voice' instead of 'exit' (Mudde 1996: 272-3). A new type of parties emerged, the so-called anti-party parties; according to Mudde (ibid.), they 'criticize' or 
even 'condemn' the established political parties, but 'they do not reject parties per se'. In the years thereafter, the debate on anti-party and challenger parties became more specific, focusing on antiestablishment parties whose emergence could be associated with the process of 'value change' and the subsequent failure of traditional parties to include the emerging issues into their narrative (Ignazi 1997: 318). Several scholars (Sartori 1976; Schedler 1996; Capoccia 2002; Abedi 2004; Hartleb 2015; Zulianello 2019) have used a range of synthetic conceptualizations in order to approach the parties that deviate from the category of political establishment.

The academic debate has been concentrating particularly on the differentiation between the parties that challenge the democratic system and those that act within it. Abedi (2004) has expanded the aforementioned concepts by proceeding to a more systematic classification of the challenger parties. More specifically, he focuses (Abedi 2004) on 'anti-political establishment parties' (APE) as a generic term, avoiding ideological or organizational explanations of their profile: APE parties could be located in either the right or the left side of the political spectrum; they could be regional or national, 'flash' or 'movement' parties, populist radical right or new left parties reflecting value change and/or popular dissatisfaction with socio-political institutions. Despite the different ideological perspectives and organizational structures in the anti-political establishment party family, these parties tend to perceive themselves as challengers to the political establishment in either policy or organizational terms, highlighting the division between the Establishment and the People and equalling the differences between governing and opposition mainstream parties (Abedi 2004: 12). This division partially overlaps with the dichotomy between the "virtuous people" and the "vile elites" that is inherent in the concept of populism (Taguieff 1995; Taggart 2002; Mudde 2004; Mudde and Rovira Kaltwasser 2013). However, parties that are against 'The Establishment' are not necessarily populist in the sense that they are neither in favor of an idea of 'The People' perceived as a homogeneous/organic entity nor against 'The Elite' as a whole. Anti-establishment parties are mainly against the governing and the political elite, but they are not against any notion of expertise and they 
lack a total of anti-elitist rhetoric. Anti-establishment parties diverge from anti-system parties (Sartori 1976) because that they do not challenge the fundamental principles of a democratic regime. Antiestablishment parties do not seek to replace the democratic framework, but they are in favour of changing the way in which democracy works (Painter 2013: 7).

Anti-establishment parties are not treated as a residual category of parties which are expected to remain permanently outside coalition governments and have limited political power. Apart from seeking to expand their electoral support for the purpose of gaining parliamentary representation, as well as to influence specific policies, anti-establishment parties have gradually developed officeseeking goals. According to the behavioural theory of party competition, office-seeking parties aim to maximize their 'control of elected office, often operationally defined in terms of government portfolios' (Strøm 1990: 567). It stands to reason that if anti-establishment parties remain challengers, outsiders and anti-party agents, they are not likely to participate in a government. However, as a result of 'external shocks, internal factors or a combination of both sets of variables' (Abedi and Schneider 2004: 3), anti-establishment parties can transform themselves into office-seeking parties. The failure of established parties to form a coalition government - as was the case in Austria after the National Council vote of October 1999, the decision of G. Fini to participate in S. Berlusconi's cabinets, or the support provided by the Danish People's Party to the minority governments of the Liberals and Conservatives in the Danish Parliament in 2001- are examples of party internal and external critical junctures that relate to changes in the behaviour of electorally relevant anti-establishment parties (Mudde 2016). To these examples we should add the cases of new left parties that have been part of governing coalitions, such as the Green parties that have joined national governments in Germany, Belgium, Finland, Austria, etc. (Müller-Romer and Poguntke 2002).

There are different coalition theories according to which multi-party governments are formed by a (moderate or large) number of parties that often are 'immediate neighbours' to each other (Sartori 
1976; Lijphart 1999: 91-96; Tsebelis and Ha 2013). Although the rule is that coalitions are made either by ideologically neighbouring parties or by 'connected' parties that are 'adjacent' in the policy field, there are also instrumentally motivated coalitions composed by parties that are not confined to a specific position along the Left-Right spectrum (Lijphart 1999: 95; Strøm 1990: 567-568). The transformation of anti-establishment parties into office-seeking parties raises fundamental questions on whether and how this change affects their vote-seeking and/or policy-seeking goals. The fact that anti-establishment parties enter government coalitions with mainstream parties may undermine their political identity, in particular when anti-establishment and mainstream parties are not close to each other with regard to policy positions and programmatic stances. However, an important question that arises from the participation of anti-establishment parties in coalition governments relates to whether these parties preserve the fundamental components of their identity concerning the challenge of the political establishment. Participating in a governing alliance with their opponents of the mainstream party arena and becoming part of it, anti-establishment parties soften their image as challengers of the party system and, to a certain extent, their anti-elite message (Vasilopoulou 2018; Krause and Wagner 2019: 3). What should happen in the case of a government coalition forged between party challengers that reject the mainstream consensus? It is expected to be an unsuccessful and short-lived alternative, not only due to the ideological gap that is likely to exist between anti-establishment parties but also as a result of the fact that anti-establishment parties could seek to offset any electoral losses caused by their participation in coalition governments by prematurely abandoning government portfolios and restoring their anti-establishment status.

\section{The anti-establishment party arena in crisis-ridden Southern Europe}

Southern European countries have experienced an unprecedented financial crisis that has affected their party system, mainly due to the fact that governing parties declined, whilst new antiestablishment parties not only emerged and/or electorally marginal challengers became relevant (Bosco and Verney 2017); more importantly, they have acquired a leading role in party and policy 
competition. During this period, anti-establishment parties of different ideological shades have evolved into notable players along the dimensions of the Western European party competition irrespective of the 'order' (first, second) of each election (Mavropoulou 2019). However, the consequences of the financial crisis cannot be directly associated with the rise of anti-establishment parties, since the party systems of prosperous Northern Europe have also been experiencing the electoral rise of parties that challenge the political establishment, despite the limited exposure of these countries to the implications of the latest financial crisis. Among the countries of Southern Europe that have been hardest hit by the crisis, Greece was an emblematic case where antiestablishment parties from the left and the right side of the political arena flourished (Teperoglou and Tsatsanis 2014; Bosco and Verney 2017).

Anti-establishment parties have a strong presence in Greece and Italy. In the Greek case, the radical left SYRIZA and the radical right ANEL became partners in coalition cabinets, the first after the parliamentary elections of January 2015 and the second after the snap general elections of September 2015. The two parties locate themselves in opposing positions along a range of policy dimensions, since SYRIZA falls into the radical left-wing spectrum with socially libertarian viewpoints (Katsourides 2016:119), whilst ANEL is placed in the populist right-wing spectrum expressing authoritarian and nationalist appeals (Matakos and Xefteris 2016: 172). The radical left SYRIZA is a constellation of leftwing parties and extra-parliamentary groups launched in the beginning of the millennium (Tsakatika 2016) that favors immigration and advocates civil, social and human rights (Gourgouris 2015), whereas the populist radical right ANEL is a nativist, anti-immigrant, populist radical right party that gives prominence to 'national issues' (Halikiopoulou and Vasilopoulou 2015; Mudde 2017a: 32; Georgiadou 2019). However, SYRIZA and ANEL were 'not so strange bedfellows' (Pappas 2015). Both parties were moving within the lines of 'national populism' (Eatwell and Goodwin 2018), prioritizing the interest of the nation against the 'corrupt elites' and the 'oligarchic system'. Both parties constituted the leading forces of the anti-Memorandum block, cultivating a radical anti-Memorandum and anti-austerity 
rhetoric surrounded by Eurosceptic views (Vasilopoulou 2018) with an economic slant. However, less research interest has been devoted to ascertaining the extent of the potential convergence between two apparently diverging parties along a range of traditional policy dimensions.

Italy is a similar case to Greece regarding to its anti-establishment potential. The context of a multifaceted crisis with economic, cultural and political dimensions impacted on the the electoral take-off of anti-establishment parties (Graziano 2018; Caiani 2019), namely the anti-immigrant and Eurosceptic populist right-wing Lega Nord (rebranded as Lega/League) and the post-democratic M5S-a configuration emerged as a grassroots rebellion that is not easily aligned along the Left-Right political spectrum - which formed a coalition government from June 2018 to August 2019, when M. Salvini, leader of the Lega and interior minister at that time, demanded snap elections. The Five Star Movement, initially against any alliances with other parties, and the League proceeded to the formation of a coalition government having readjusted their populist electoral pledges due to country's macro-economic restrictions and the discipline enforced by the European authorities (Moschella and Rhodes 2020). However, the short-run governing co-existence of the two coalition partners has brought to light their immense difficulty to balance between electoral responsiveness and government responsibility (Mair 2014), a fact that jeopardized country's weak economy and did not address its macro-economic challenges (Moschella and Rhodes 2020). Moreover, the heightened chasm between the 5SM and the League around the policy priorities of the coalition government in conjunction with their discrepancies over budgetary and migration policies accelerated the dissolution of their governing alliance.

Since the academic debate focuses on the strategic perspectives of the anti-establishment coalition partners confirming that their governing motivations are driven by office-seeking (Giannetti et al. 2018; Rori 2016) rather than converging policymaking goals, one of the main purposes of this paper is to examine convergences and divergences between anti-establishment governing parties by 
concentrating on their programmatic stances and policy positions as stated officially in the party manifestos. Our research goal is to identify the official programmatic stances and policy positions of anti-establishment coalition partners across a range of policymaking dimensions and issue areas in order to explore any potential associations/links. Our aim is to compare the official policy stances of the parties that constituted the SYRIZA-ANEL and the M5S-League coalition governments in order to examine the policy basis which stimulated the government formation of a dyad of ideologically diverging anti-establishment parties.

\section{Data and Methodology}

Party manifestos have been widely used as explanatory indicators for party competition (Benoit and Laver 2006). The positions of parties along policymaking dimensions reflect their ideology, are closely linked to their identity in the public and electoral sphere (Wagner 2012) and provide evidence for the ideological distance among parties along the policy space of party systems (Sartori 1976; Dalton 2008). However, party positions and the salience with which parties address certain issues are not unconnected to each other. Party positions and issue salience are complementary at least for the core issues (e.g. the environment for the Greens or immigration for the Populist Radical Right), in the sense that they are 'clearly part' of party identity (Kriesi et al. 2006; Wagner 2012). In this paper we are looking for ideological convergences or divergences between SYRIZA and ANEL on the one hand, and League and M5S on the other hand, by exploring the issue salience and party positions on policy dimensions (Wagner 2012). Our data are derived from the processing of party manifestos through which political parties present their 'official' statements on a range of policy issues (Benoit and Laver 2006), reflecting their ideological priorities and 'valid party positions' (Eder et al. 2017). More specifically, this paper draws data from the Comparative Manifesto Project (CMP/MARPOR) (Volkens et al. 2018). 
$\mathrm{CMP} / \mathrm{MARPOR}$ data measure the extent of salience of policy issues in party programs over a long time period by including most of the political parties across European party systems and providing the opportunity for a comparative interpretation of party competition (Budge et al. 2001). Although CMP/MARPOR data are widely used among numerous studies (i.a. Budge and Klingemann 2001; Adams et al. 2006; Abou-Chadi and Krause 2018), nonetheless they have been criticized by several scholars (Dinas and Gemenis 2010; Gemenis 2013). Their criticism concerns the absence of reliable estimates on policy positions, particularly along the left-right scale. ${ }^{2}$

Despite methodological limitations, CMP/MARPOR dataset is extensively used among scholars for the interpretation of party competition, comparatively and/or over time (Budge 2013). The research purpose of this paper is to explore the positions of parties that constituted both anti-establishment coalition alliances along a range of policy dimensions, tracing potential ideological links that might explain their convergence. Studies on parties -far right, populist or anti-establishment- are divided into two basic groups depending on the factors that explain their rise: 'demand-side' factors refer to a variety of reasons that shape voters' preferences, whereas 'supply-side' factors concentrate on the conditions under which specific types of parties are facilitated to emerge in the party arena or to increase their vote share in party competition (Mudde 2007; Rydgren 2007; Georgiadou, Rori and Roumanias 2018). Among the demand-side reasons which motivate voters to support party challengers are socio-economic and cultural conditions that create grievances, making people more susceptible to populist and anti-establishment appeals (Norris and Inglehart 2019). Demand-side

\footnotetext{
2 Instead of CMP, expert surveys (CHES) (Bakker et al. 2015), through which political experts locate parties on structured scales along a range of policy dimensions, could be used as an alternative data source for measuring party positions (Huber and Inglehart 1995). However, their methodological limitations are also under scrutiny; the method based on the judgments of specialists is subject to criticisms (Laver 2001; Mair 2001) associated with the time frame, the subjectivity of experts' criteria in conjunction with the kind of material they take into consideration in order to place parties along policy scales, etc. (Budge 2000).
} 
explanations are complemented by external and internal supply-side parameters which played a significant role for the rise of the anti-establishment challengers and their consolidation in the party arena. In the literature, supply-side factors are grouped into political opportunities, such as electoral rule or party competition (Norris 2005; Arzheimer 2009) and the parties' ideological and organizational properties (Goodwin 2006; Art 2011). The exogenous components of supply interact with the factors of demand (Arzheimer and Carter 2006) as well as with internal supply-side factors. This paper focuses on the interrelationship between the external and internal supply-side framework, since the configuration of party competition occurs through the ideology of parties and their placement on multiple policy dimensions.

Using the Manifesto Project dataset we take a closer look at issue salience and parties' positions along a range of fundamental policy dimensions that tend to determine the structures of modern European party systems during the last decades (Kriesi et al. 2006). On a first level, we are interested in exploring the extent of the anti-Memorandum issue salience ${ }^{3}$ (see Appendix 1 ) in the party manifestos of SYRIZA and ANEL over the period 2012-2015. In doing so, we determine the evolution of their antiMemorandum stance from 2012 onwards and whether their opposition against the Memorandum served as a background for the formation of the SYRIZA-ANEL coalition government. Then we turn our interest to the measurement of the party positions of both anti-establishment coalition alliances based on the extent of the issues' salience in party manifestos. Therefore, the calculation of party positions across the traditional left-right dimension ensues from the subtraction between the sum of the quasi-quotes relating to the right cluster and the corresponding left cluster (see Appendix 1). Subsequently, we rescale the CMP left-right scale - which traditionally ranges from -100 to +100 , where ' -100 ' means a totally left-wing oriented party manifesto and ' +100 ' means a totally right-wing

\footnotetext{
${ }^{3}$ Issue salience ranges from 0 to 100 , where ' 0 ' means that the party ignores a specific policy issue and ' 100 ' means that the party devotes all its manifesto-statements to this issue.
} 
orientation - to the more familiar 11-point scale which runs from 0 (left) to 10 (right). We follow a similar calculation as above in order to identify the parties' positions along an aggregate socioeconomic dimension which incorporates economic and European integration issues (Katsanidou and Otjes 2016) when we measure the party positions of SYRIZA and ANEL. Since the outbreak of the financial crisis, there is strong evidence about an interrelationship of economic issues with European programmatic stances, in particular by political parties that fall within the anti-Memorandum block (Otjes and Katsanidou 2017). The fact that the coding categories of the Manifesto Project dataset which appertain to the socio-economic dimension include macro and micro-economic issues as well as issues relating to the spectrum of social protection might enable us to further refine this dimension. The socio-cultural dimension (known as GAL-TAN) extends from social liberalism to social conservatism (Polk et al. 2017: 2). The placement of parties along the socio-cultural dimension (see Appendix 1) occurs via the subtraction between the sum of the quasi-quotes related to the green/alternative/libertarian (GAL) cluster and the corresponding traditionalist/authoritarianist/nationalist (TAN) cluster (Hooghe et al. 2002).

\section{Findings and Discussion}

We now turn to the calculation of the anti-Memorandum issue salience for SYRIZA and ANEL -the antiMemorandum contestation was irrelevant in Italy and therefore we focus on the Greek case- and then we proceed to the identification of positions of SYRIZA-ANEL and the M5S-League governing alliances on the left-right, the socio-economic and the socio-cultural dimension. It should first be noted that our findings confirm the anti-Memorandum orientation of SYRIZA and ANEL, two parties that were regarded as the leading players in the 'anti-Memorandum camp' (Malkoutzis 2012: 8-9). However, after the double 'earthquake' elections of May/June 2012 both parties began to dampen their polemic against the Memorandum (MoU) that was associated with 'imposed' austerity measures on the Greek economy and excessive curtailments of public spending, downsizing the public sector according to the Troika's (IMF, ECB and EC) evaluations (Vasilopoulou and Halikiopoulou 2013; 
Chrysoloras 2013). In concrete terms, SYRIZA included 56 anti-Memorandum references in its May 2012 party manifesto whereas ANEL incorporated 36 anti-Memorandum references; in the June 2012 election, SYRIZA confined the number of its anti-Memorandum viewpoints to 46 , while the corresponding references of ANEL remained unchanged. SYRIZA's January 2015 party manifesto contained significantly fewer references $(5)^{4}$ against the Memorandum and the international actors under the economic 'surveillance' of whom Greece was deemed to be placed, confining even more the salience of the anti-austerity rhetoric after the parliamentary elections of May 2012. As for ANEL, they also started to soften their opposition against the Memorandum after the elections of June 2012. On the run up to the January 2015 parliamentary election, SYRIZA extended its viewpoints along a variety of policymaking issues beyond anti-austerity policies, a fact that reduced the antiMemorandum issue salience identified in its previous party manifestos. In the same vein, ANEL's openly anti-Memorandum views (3) were remarkably decreasing despite the fact that a sizeable part of their manifesto was still devoted to anti-austerity aspects. The political ambitions, notably of SYRIZA, and its gradual transformation into a governing party -without abandoning the discourse of challenging the traditional political establishment- justify the reduction of the anti-Memorandum statements included in the party manifesto of the January 2015 parliamentary election, although the party's narrative in the media, as well as the everyday political jargon of SYRIZA, were still predominantly against the Memorandum (Figure 1). With regard to their orientation vis-à-vis the economic adjustment program, both parties had been converging since 2012, a trend that facilitated the formation of the SYRIZA-ANEL coalition government in 2015. In the September 2015 legislative election, the level of political divergences between SYRIZA and ANEL as regards the salience of the anti-Memorandum issue seems to be balanced. Both parties' manifestos incorporated anti-austerity statements against the 'neo-liberal Europe' and the 'weak-knead' domestic political establishment.

\footnotetext{
${ }^{4}$ Within the parentheses we mention the number of anti-Memorandum references that were included in SYRIZA's and ANEL's party manifestos for the 2015 January election.
} 
[Figure 1 here]

Figure 2 portrays the positions of SYRIZA and ANEL on the 11-point scale of the traditional left-right dimension over the period 2012-2015. Our findings confirm the researchers' estimation, since the leftwing placement of SYRIZA remained constant, displaying only slight shiftings along the left-wing spectrum of the left-right aggregate scale throughout the period under consideration. During the January 2015 Parliamentary election, SYRIZA marked its most leftist position along the left-right policy space, a fact that could be associated with the adoption of an anti-austerity programmatic agenda balancing economic interventionist with social-protectionist policies. However, a few months later, in the September 2015 Parliamentary election, SYRIZA converged towards a more centrist position due to the signing of the third Memorandum and the subsequent readjustment of the party's economic policy, including aspects of the free market economy in its programmatic agenda. As for ANEL, we observe the party's fluctuating positioning along the left-right dimension. In the 2012 twin Parliamentary elections ANEL touched the left side of the left-right scale, even though it falls into the populist radical right party family which is traditionally situated in the right-wing spectrum, reflecting a socially authoritarian and nationalist value profile. Taking into account the fact that the programmatic agenda of ANEL for the May/June Parliamentary elections was particularly oriented at social protectionist perspectives, including extensive references against austerity policies and statements in favour of welfare state expansion, it might enable us to comprehend the paradoxical and circumstantial positioning of ANEL in the centre-left spectrum of the left-right dimension. ANEL have been stabilised within the traditional ideological borders of the populist radical right party family since the General election of January 2015 due to the further salience of authoritarian policy aspects associated with the restriction of immigration and the preservation of traditional moral values. SYRIZA and ANEL seem to present more convergent positions along the left-right dimension in the June 2012 legislative elections. However, the discrepancy between the left-right positions of the governing partners widened considerably after the January/September 2015 elections, as SYRIZA was constantly positioned on the left-wing spectrum while ANEL moved towards the right-wing side of the left-right 
dimension, adopting authoritarian and exclusionist socio-cultural policy perspectives. The gradual collapse of the pro-Memorandum vs. anti-Memorandum division, which determined the configuration of party competition during the 2012 double Parliamentary elections, contributed to the realignment of parties within their traditional ideological space along the left-right dimension.

[Figure 2 here]

The divide on the aggregate socio-economic dimension is between free-market economy and economic protectionism. As explained in the previous section, European issues were integrated into this area for the Greek case and the period 2012-2015. Figure 3 plots the location of SYRIZA and ANEL on this dimension. Between May and June 2012 both parties were placed near each other within the social protectionist pole. Subsequently, after the double legislative elections of 2012 , the Independent Greeks started moving towards a pro-market direction, gradually increasing the distance from SYRIZA which moved slightly to the centre of the socio-economic axis. The distance between SYRIZA and ANEL on the socio-economic dimension is on an upward trend, reaching a peak in the September 2015 elections even though it might be expected that the governing partners would adopt a more converging socio-economic agenda after the ratification of the third Memorandum and the subsequent readjustment of their policies according to the terms of the bailout agreement. More specifically, the junior partner (ANEL) promoted a distinctive profile on socio-economic issues probably to secure itself against electoral losses as a result of its participation in the government, which is expected to force minor coalition parties to converge with the policy positions of the senior ones (Adams et al. 2006). In the case of ANEL, its electoral survival depended on the party's capacity to maintain policy positions that were dissimilar to those of SYRIZA and less moderate within the frame of this government.

[Figure 3 here]

Figure 4 displays the placements of the M5S and the League on the left-right dimension along the aggregate socio-economic dimension for the 2018 General election. We observe that the governing partners were characterised by a relative convergence vis-à-vis their positions on the left-right axis 
confirming the hybrid character of the M5S which is a mixture of left-wing and right-wing discoursive properties. However, the League was situated almost at the center of the left-right spectrum. This finding could not be interpreted as an abandonment of its populist radical right-wing quality; having acquired a potential governing dynamic, the League emphasized along its manifesto the cultivation of an economic programmatic agenda surrounded by economic protectionist claims and welfare chauvinism criteria. More specifically, both coalition partners were located near each other within the economic protectionist pole indicating that despite divergencies in socio-economic issues (e.g. flat tax, basic income) the governing allies were not complete 'strangers' since their positions are mostly converging on issues with socio-economic claims.

[Figure 4 here]

As mentioned above, the socio-economic dimension contains two subsets of interrelated issues, one that integrates free market positions and a second that incorporates stances relating to social protection and the welfare state. As a further step, we decided to split the socio-economic dimension and create two sub-dimensions (see Appendix 1). The first of these includes the parties' positions on macro- and micro-economic issues, while the second sub-dimension involves their positions on social protection and welfare. Figure 5.1 confirms that SYRIZA and ANEL almost overlap on economic issues up to January 2015. Thereafter, ANEL moved towards the pro-market pole, whilst SYRIZA zigzagged around the centre of the economic sub-dimension. However, SYRIZA and ANEL have converged on the social protectionist/welfare sub-dimension throughout the whole period (from May 2012 to September 2015), as Figure 5.1 shows. Their distance remained relatively stable over time, having slightly increased only during the January 2015 parliamentary elections, with SYRIZA trying to win the elections with an anti-austerity and radical left agenda.

[Figures 5.1 here]

Figure 5.2 plots the location of the M5S and the League on the two economic sub-dimensions. Here we find that both coalition partners converged in placements on the economic sub-dimension 
remaining, even marginally, within the economic interventionist pole; the M5S and the League overlapped on the welfare sub-dimension preserving their social protectionist orientation.

[Figures 5.2 here]

Figure 6 displays the placements of SYRIZA and ANEL on the aggregate socio-cultural dimension relating to party attitudes towards lifestyle, civil liberties, issues of security and perspectives of the world order (Hooghe et al. 2002). Overall, we observe that the governing partners were characterised by a striking discrepancy vis-à-vis their attitudes on the GAL-TAN axis. However, the observed discrepancy between SYRIZA and ANEL demonstrated a constant trend during the 2012 double Parliamentary elections that became deeper in the January 2015 elections, confirming the inclusivistlibertarian policy orientation of SYRIZA and the exclusionist-authoritarian profile of ANEL (Stavrakakis et al. 2016: 12). The socio-cultural dimension indicates the expected ideological divergence between SYRIZA and ANEL due to the parties' contrasting viewpoints on a variety of issues associated with 'law and order', individual rights and freedoms, immigration/minorities. The distance between SYRIZA and ANEL along the socio-cultural dimension seems to be minimized in the September 2015 legislative election. This is not a result of ANEL becoming less exclusionist and authoritarian in socio-cultural issues; after their first participation in the coalition government led by SYRIZA, the Independent Greeks tended to focus more on an economic programmatic agenda with a pro-market slant, brushing under the carpet their radical right-wing profile.

[Figure 6 here]

Figure 7 displays the placements of the M5S and the League on the horizontal socio-cultural dimension along the vertical European integration dimension. According to our findings, the M5S and the League demonstrated a relative ideological divergence since the M5S was placed in the libertarian pole (GAL) while the League was slightly situated at the authoritarian (TAN) spectrum of the socio-cultural axis. The left-libertarian orientation of the M5S could be attributed to the environmentalist claims as a key element of party's agenda. On the other hand, the unprecedent placement of the League almost at the center of that dimension was not consistent to the traditional populist radical right-wing profile 
of the party but it could be associated with the remarkable salience of the environmentalist issues - a left-wing occupied policy area - by the League. Our findings confirm the convergence between the two parties vis-à-vis the issue of European integration. The M5S and the League preserved their critical Eurosceptic stance - however, without embracing the outright rejection of European integration and having dropped their more overt anti-European stances.

[Figure 7 here]

\section{Conclusions}

In crisis-ridden Southern Europe, the consolidation of anti-establishment parties goes hand in hand with the electoral punishment of the incumbents. The Greek and the Italian party system have become relevant case-studies for the analysis of the anti-establishment spectrum, regarding both the rise of anti-establishment parties and the formation of anti-establishment coalition governments.

The January 2015 Greek general election and the subsequent September 2015 election failed to result in a single party government as an after-effect of the Greek party system's radical transformation since the 2012 double Parliamentary elections. SYRIZA's victory without an outright majority in Parliament led to the formation of a government coalition with ANEL, a party that despite its ideological zigzagging was situated at the right-wing pole of the left-right spectrum. The government coalition of SYRIZA and ANEL has been described as 'unholy', 'bizarre', 'strange' or 'paradoxical'. The complex outcome of the 2018 Italian General elections marked the further transformation of the Italian party system due to the fact that two anti-establishment parties, the Five Star Movement and the League, were evolved into the two most notable party forces that unprecedentedly proceeded to the formation of a coalition government. The alliances forged between SYRIZA and ANEL on the one hand and the Five Star Movement and the League on the other hand were unexpected since the partners of both coalition governments were surrounded by contrasting viewpoints. Beyond apparent divergences, we searched for the rationale behind parties' choice to join a coalition. Concentrating on supply-side explanations, 
we explored the policymaking factors that facilitated the formation of the anti-establishment coalition governments.

Using the Comparative Manifesto Project dataset, we focused on the operationalization of the official party programs of SYRIZA-ANEL, as well as of the Five Star Movement-League. Regarding the Greek case-study, our efforts were concentrated on identifying elective affinities between SYRIZA and ANEL that went beyond the rather circumstantial pro-Memorandum vs. anti-Memorandum division. Briefly, the findings indicate that SYRIZA and ANEL were not complete strangers as regards their programmatic stances and policy positions. Our results provide evidence that unsettles the argument of the 'strategic' alliance of SYRIZA and ANEL and create doubts about the alleged superiority of the ideological distance on the left-right dimension that does exist between the two governing parties. In January 2015 SYRIZA and ANEL formed a coalition government, the cementing force of which was more than their party identities as challengers of the 'old' political establishment. Apart from the antiestablishment quality that characterized both parties and the high salience of the anti-Memorandum issue up the 2012 twin legislative elections, they demonstrated remarkable policy convergences, a fact that was reflected in the continuation of their cooperation as governing partners after the September 2015 parliamentary election. Both parties converged on the economic agenda relating to macro and micro-economic issues up to the January 2015 Parliamentary election, whereas they were constantly close on social protectionist and welfare issues. However, a chasm remained between them in socio-cultural issues, confirming the lack of reciprocal influence between them along the GAL-TAN dimension.

Hence, we find evidence which confirms that the outcome of the January 2015 election did not result in either a governing marriage of convenience or a purely policymaking love match, as convergences and divergences in a variety of stances were apparent between the two governing parties. Despite the centrist shift of SYRIZA and the pro-market reorientation of ANEL along the socio-economic dimension 
in the September 2015 election, programmatic linkages were preserved. However, the policymaking convergence between coalition partners remained weak during the second half of the September 2015 SYRIZA-ANEL cabinet; it was exclusively detected in the European integration dimension. This finding demonstrates aspects of an office-seeking orientation of this alliance, that was taking shape once the pro-Memorandum vs. anti-Memorandum division ceased to determine the policy space of the Greek party system. The gradual relaxation of this divide, in conjunction with the Prespa agreement that was fully supported by SYRIZA, have brought to light divergences between SYRIZA and ANEL along a range of policy dimensions, delivering the coup de grâce to the SYRIZA-ANEL coalition government.

Focusing on the Italian case-study, our findings demonstrate that the M5S and the League were not ideologically distant from each other along a range of programmatic stances and policy positions indicating that the 'unprecedent' coalition of the 2018 elections occurred between two ideologically 'neighbouring' parties with converging policymaking goals. The M5S and the League appeared close each other along the left-right dimension, whereas they were characterised by remarkable policy convergences along the socio-economic dimension consisted of macro/micro and social protectionist issues. Coalition partners remained unexpectedly close to each other along the socio-cultural dimension, a fact that confirms that the increasing salience of environmentalist issues could upend the traditional ideological interrelationships. The existence of ideological commonalities between the two parties did not prevent the confrontations within the coalition. The outcome of the 2019 European elections which signaled the reversal of the electoral dynamics between the M5S and the League - as the latter became the largest political party in terms of vote share - in conjunction with their heightened discrepancies with regard to budgetary and immigration policies led to the premature dissolution of their governing alliance. 
Anti-establishment parties have evolved into remarkable players affecting the balances of governing competition. However, anti-establishment parties seem to present a hybrid status between asserting office and keeping their unconventional opposition by challenging the political establishment, a role that is sustained even if anti-establishment parties enter a coalition government. Future research should focus on anti-establishment parties and coalitions in a comparative direction; the Greek and the Italian anti-establishment coalition government are two relevant cases, that might provide a wellrounded view regarding the nature of governing 'marriages' between ideologically diverging antiestablishment parties.

\section{References}

Abedi, A. 2004. Anti-Political Establishment Parties. A Comparative Analysis (London and New York: Routledge).

Abedi, A. and Schneider, S. 2004. Adapt or Die! Organizational Change in Office-Seeking Anti-political Establishment Parties (Winnipeg, Manitoba: Paper presented at the Annual General Meeting of the Canadian Political Science Association).

Abou-Chadi, T., and Krause, W. 2018. “The Causal Effect of Radical Right Success on Mainstream Parties' Policy Positions: A Regression Discontinuity Approach", British Journal of Political Science: 1-19, DOI: https://doi.org/10.1017/S0007123418000029.

Adams, J., Clark, M., Ezrow, L. and Glasgow, G. 2006. "Are Niche Parties Fundamentally Different from Mainstream Parties? The Causes and the Electoral Consequences of Western European Parties' Policy Shifts, 1976-1998", American Journal of Political Science 50(3): 513-529.

Algan, Y., Beasley, E., Cohen, D. and Foucault, M. 2018. "The Rise of Populism and the Collapse of the LeftRight Paradigm: Lessons from the 2017 French Presidential Election" (Discussion Paper 13103, CERP)

Art, D. 2011. Inside the Radical Right: The Development of Anti-Immigrant Parties in Western Europe (Cambridge: Cambridge University Press). 
Arzheimer, K. and Carter, E. 2006. "Political Opportunity Structures and Right-Wing Extremist Party Success", European Journal of Political Research 45(3): 419-443.

Arzheimer, K. 2009. "Contextual Factors and the Extreme Right Vote in Western Europe, 1980-2002", American Journal of Political Science 53(2): 259-275.

Aslanidis, P. and Rovira Kaltwasser, C.-R. 2016. "Dealing with Populists in Government: the SYRIZA-ANEL Coalition in Greece", Democratization 23(6): 1077-1091.

Bakker, R., Mareuge, C., Marguerit, D. and Palier, B. 2015. “Measuring Party Positions in Europe: The Chapel Hill Expert Survey Trend File, 1999-2010", Party Politics 21: 143-152.

Benoit, K. and Laver, M. 2006. Party Policy in Modern Democracies (London: Routledge).

Bosco, A. and Verney, S. 2017. "From Electoral Epidemic to Government Epidemic: The Next Level of the Crisis in Southern Europe", South European Society and Politics 21(4): 383-406.

Budge, I. 2000. "Expert Judgements of Party Policy Positions: Uses and Limitations in Political Research", European Journal of Political Research 37: 103-113.

Budge, I. and Klingemann, H.-D. 2001. "Finally! Comparative Over-Time Mapping of Party Policy Movement", in I. Budge, H.-D. Klingemann, A. Volkens, J. Bara, and E. Tanenbaum (eds.) Mapping Policy Preferences - Estimates for Parties, Electors, and Governments 1945-1998 (Oxford: Oxford University Press).

Budge, I., Klingemann, H.-D., Volkens, A. and Bara J. 2001. Mapping Policy Preferences. Estimates for Parties, Electors and Governments 1945-1998 (Oxford: Oxford University Press).

Budge, I. 2013. "The "Paradox of the Manifestos": Satisfied Users, Critical Methodologists", retrieved September 26, 2019 from https://manifesto-project.wzb.eu/down/papers/budge paradox.pdf .

Caiani, M. 2019. "The populist parties and their electoral success: different causes behind different populisms? The case of the Five-star Movement and the League", Contemporary Italian Politics 11(3): 236-250.

Capoccia, G. C. 2002. “Anti-System Parties: A Conceptual Reassessment”, Journal of Theoretical Politics 14(1): 9-35.

Chrysoloras, N. 2013. Rebuilding Eurozone's Ground Zero: A Review of the Greek Economic Crisis (London: GreeSE Paper No. 66). 
Dalton, R. 2008. "The Quantity and the Quality of Party Systems: Party System Polarization, Its Measurement, and Its Consequences", Comparative Political Studies 41(7): 899-920.

Dinas, E. and Gemenis, K. 2010. "Measuring Parties' Ideological Positions with Manifesto Data: A Critical Evaluation of the Competing Methods", Party Politics 16(4): 427-450.

Eatwell, R. and Goodwin, M. 2018. National Populism: The Revolt Against Liberal Democracy (London: Pelican). Eder, N., Jenny, M. and Müller, W. 2017. "Manifesto Functions: How Party Candidates View and Use their Party's Central Policy Document", Electoral Studies 45: 75-87.

Ellinas, A.-A. 2015. Neo-Nazism in an Established Democracy: The Persistence of Golden Dawn, South European Society and Politics 20(1): 1-20.

Gemenis, K. 2013. "What to Do (and Not to Do) with the Comparative Manifestos Project Data", Political Studies 61: 3-23.

Georgiadou, V., Rori, L. and Roumanias, C. 2018. “Mapping the European Far Right in the $21^{\text {st }}$ Century: A MesoLevel Analysis", Electoral Studies 54: 103-115.

Georgiadou, V. 2019. The Far Right in Greece, 1965-2018 (Athens: Kastaniotis) (in Greek).

Giannetti, D. and Pedrazzani, A. and Pinto, L. 2018. "The Rising Importance of Non-Economic Policy Dimensions and the Formation of the Conte Government in Italy", Italian Political Science 13(2): 27-44.

Goodwin, M.-J. 2006. "The Rise and Faults of the Internalist Perspective in Extreme Right Studies", Representations 42: 347-364.

Gourgouris, S. 2015. The SYRIZA Problem: Radical Democracy and Left Governmentality in Greece (Opendemocracy, retrieved February 10, 2020 from https://www.opendemocracy.net/en/caneurope-make-it/syriza-problem-radical-democracy-and-left-governmentality-in-g/ ).

Halikiopoulou, D. and Vasilopoulou, S. 2015. SYRIZA Won with a Radical Left Programme, but Keeping the Middle Class on Side May Be Key to Retaining Power (EUROPP - European Politics and Policy, retrieved February 10, 2020 from http://bit.ly/1zbEf1u).

Hartleb, F. 2015. "Here to Stay: Anti-Establishment Parties in Europe", European View 14(1): 39-49. 
Hooghe, L., Marks, G. and Wilson, C.-J. 2002. "Does Left/Right Structure Party Positions on European Integration?", Comparative Political Studies 35: 965-989.

Huber, J. and Inglehart, R. 1995. "Expert Interpretations of Party Space and Party Locations in 42 Societies", Party Politics 1(1): 73-111.

leraci, G. 2019. "Party system and coalition governments in post-WWII Italy", in M. Evans (ed.), Coalition Government as a Reflection of a Nation's Politics and Society, A Comparative Study of Parliamentary Parties and Cabinets in 12 Countries (London: Routledge).

Ignazi, P. 1992. "The Silent Counter-Revolution: Hypotheses on the Emergence of Extreme Right-Wing Parties in Europe", European Journal of Political Research 22(1): 3-34.

Ignazi, P. 1997. "New Challenges: Postmaterialism and the Extreme Right," in M. Rhodes, P. Heywood and V. Wright (eds.), Developments in West European Politics, (New York: St. Martin's Press): 300-319.

Inglehart, R. 1984. "The Changing Structure of Political Cleavages in Western Society," in R. Dalton, S. Flanagan and P. Beck (eds.), Electoral Change in Advanced Industrial Democracies (Princeton, NJ: Princeton University Press): 25-69.

Katsanidou, A. and Otjes, S. 2016. "How the European Debt Crisis Reshaped National Political Space: The Case of Greece", European Union Politics 17(2): 242- 261.

Katsourides Y. 2016. Radical Left Parties in Government. The Case of Syriza and AKEL (London: Palgrave Macmillan).

Katz, R. S. and Mair, P. 1995. "Changing Models of Party Organization and Party Democracy: The Emergence of the Cartel Party" Party Politics 1(1): 5-28.

Krause, W. and Wagner, A. 2019. "Becoming Part of the Gang? Established and Nonestablished Populist Parties and the Role of External Efficacy", Party Politics: 1-13.

Kriesi, H., Grande, E., Lachat, R., Dolezal, M., Bornschier, S. and Frey, T. 2006. "Globalization and the Transformation of the National Political Space: Six European Countries Compared", European Journal of Political Research 45(6): 921-956. 
Laver, M. 2001. "Why Should we Estimate the Policy Position of Political Actors?”, in M. Laver (ed.), Estimating the Policy Position of Political Actors (London: Routledge).

Lijphart, A. 1999. Patterns of Democracy. Government Forms and Performance in Thirty-Six Countries (New Haven and London: Yale University Press).

Lipset, S. M. and Rokkan, S. 1967. "Cleavage Structures, Party Systems, and Voter Alignments: An Introduction", in S. M. Lipset and S. Rokkan (eds.), Party Systems and Voter Alignments (New YorkLondon: The Free Press): 1-64.

Mair, P. 2001. "Searching for the Positions of Political Actors: A Review of Approaches and a Critical Evaluation of Expert Surveys", in M. Laver (ed.), Estimating the Policy Positions of Political Actors (London: Routledge).

Mair, P. 2014. "Representative versus Responsible Government on Parties", in P. Mai (ed.), Party Systems and Democracy (Colchester: ECPR Press).

Malkoutzis, N. 2012. Greece's Painful Political Transition. Analysis of the Upcoming National Elections (Berlin: Friedrich Ebert Stiftung).

Matakos, K. and Xefteris, D. 2016. "Election Note: The September 20, 2015 Parliamentary Election in Greece", Electoral Studies 43: 172-176.

Mavropoulou, E. 2019. "Voting for Far-Right Parties in the 2014 European Parliament Elections", Science and Society 38: 50-77.

Morlino, L. and Raniolo F. 2017. The Impact of the Economic Crisis on South European Democracies (Basingstoke: Palgrave MacMillan).

Moschella, M. and Rhodes, M. 2020. "A tale of two populisms. The League and the Five star Movement in power", Contemporary Italian Politics 12(2): 112-125.

Mudde, C. 1996. "The Paradox of the Anti-Party-Party: Insights from the Extreme Right", Party Politics 2(2): $265-276$.

Mudde, C. 2004. "The Populist Zeitgeist", Government and Opposition, 39(4): 542-563.

Mudde, C. 2007. Populist Radical Right Parties in Europe (Cambridge: Cambridge University Press). 
Mudde, C. and Rovira Kaltwasser, C. 2013. "Exclusionary vs. Inclusionary Populism: Comparing Contemporary Europe and Latin America", Government and Opposition, 48: 147-174.

Mudde, C. (ed.). 2017. The Populist Radical Right: A Reader (London and New York: Routledge).

Mudde, C. 2017a. SYRIZA. The Failure of the Populist Promise (Georgia and Athens: Palgrave Macmillan).

Müller-Romer, F. and Poguntke, T. (eds.). 2002. Green Parties in National Governments (London and Portland, OR: Frank Cass).

Norris, P. 2005. Radical Right: Voters and Parties in the Electoral Market (Cambridge, UK: Cambridge University Press).

Norris, P. and Inglehart, R. 2019. Cultural Backlash: Trump, Brexit and Authoritarian Populism (New York: Cambridge University Press).

Otjes, S. and Katsanidou, A. 2017. "Beyond Kriesiland: EU integration as a Super Issue after the Eurocrisis", European Journal of Political Research 56: 301-319.

Painter, A. 2013. Democratic Stress, the Populist Signal and Extremist Threat: Call for a New Mainstream Statecraft and Contact Democracy (London: Policy Network).

Pappas, T. 2015. Not so Strange Bedfellows: Makinbg Sense of the Coalition between SYRIZA and the Independent Greeks (OpenDemocracy, retrieved September 6, 2019 from https://www.opendemocracy.net/en/can-europe-make-it/not-so-strange-bedfellows-making-senseof-coalition-between-syriza/).

Pirro, A. 2018. "The polyvalent populism of the 5 Star Movement", Journal of Contemporary European Studies 26(4): 443-458.

Poguntke, T. 1992. "Between Ideology and Empirical Research. The Literature on the German Green Party", European Journal of Political Research 21(4): 337-356.

Rori, L. 2016. "The 2015 Greek Parliamentary Elections: From Great Expectations to No Expectations", West European Politics 39(6): 1323-1343.

Rori, L. 2020. The 2019 Greek Parliamentary Election: Retour à la Normale, West European Politics 43(4): 10231037. 
Rydgren, J. 2007. "The Sociology of the Radical Right", Annual Review of Sociology 33: 241-262.

Sartori, G. 1976. Parties and Party Systems: A Framework for Analysis (Cambridge: Cambridge University Press).

Schedler, A. 1996. “Anti-Political-Establishment Parties", Party Politics 2(3): 291-312.

Stavrakakis, Y., Andreadis, I. and Katsambekis, G. 2016. “A New Populism Index at Work: Identifying Populist Candidates and Parties in the Contemporary Greek Context", European Politics and Society: 1-19.

Strøm, K. 1990a. "A Behavioral Theory of Competitive Political Parties", American Journal of Political Science 34: 565-598.

Taggart, P. 2002. "Populism and the Pathology of Representative Politics", in Y. Mény and Y. Surel (eds.), Democracies and the Populist Challenge (New York: Palgrave Macmillan): 62-80.

Taguieff, P-A. 1995. "Political Science Confronts Populism: From Conceptual Mirage to a Real Problem”, Telos 103: 9-43.

Teperoglou, E. and Tsatsanis, E. 2014. "Dealignment, De-legitimation and the Implosion of the Two-Party System in Greece: The Earthquake Election of 6 May 2012", Journal of Elections, Public Opinions and Parties 24(2): 222-242.

Tsakatika, M. 2016. SYRIZA's Electoral Rise in Greece: Protest, Trust and the Art of Political Manipulation, South European Society and Politics 21(4): 519-540.

Tsatsanis, E. 2018. "The Swift Unravelling: Party System Change and Deinstitutionalization in Greece during the Crisis," in M. Lisi (ed.), Party System Change, the European Crisis and the State of Democracy (London and New York: Routledge): 115-136.

Tsebelis, G. and Ha, E. 2013. "Coalition Theory: A Veto Players' Approach", European Political Science Review 6(3): 331-357.

Vasilopoulou, S. 2018. The Party Politics of Euroscepticism in Times of Crisis: The Case of Greece, Politics 38(3): 311-326.

Vasilopoulou, S. and Halikiopoulou, D. 2013. "In the Shadow of Grexit: The Greek Election of 17 June 2012", South European Society and Politics 18(4): 523-542. 
Volkens, A., Krause, W., Lehmann, P., Matthieß, T., Merz, N., Regel, S. and Weßels, B. 2018. The Manifesto Data Collection. Manifesto Project (MRG/CMP/MARPOR). (Version 2018b. Berlin: Wissenschaftszentrum Berlin für Sozialforschung).

Van Spanje, J. 2011. "Keeping the Rascals in: Anti-Political-Establishment Parties and their Cost of Governing in Established Democracies", European Journal of Political Research 50: 609-635.

Wagner, M. 2012. "When Do Parties Emphasize Extreme Positions? How Strategic Incentives for Policy Differentiation Influence Issue Importance", European Journal of Political Research 51(1): 64-88.

Zulianello, M. 2019. Anti-System Parties. From Parliamentary Breakthrough to Government (London and New York: Routledge). 


\section{Appendix 1}

\section{CMP/MARPOR dataset 2018}

Coding category: 103.2 Foreign Financial Influence

Negative references and statements against international financial organisations or states using monetary means to assert strong influence over the manifesto or other states. May include:

- Statements against the World Bank, IMF etc.;

- Statements against the Washington Consensus;

- Statements against foreign debt circumscribing state actions.

The scale of the anti-Memorandum issue salience occurs via the following calculation: $103.2 * 100 /$ number of quasi-sentences

\section{Creation of the Left-Right aggregate dimension}

\begin{tabular}{|l|r|}
\hline Left-wing policy cluster & Right-wing policy cluster \\
\hline per103 Anti-imperialism & per104 Military positive \\
\hline per105 Military negative & per203 Constitutionalism: positive \\
\hline per106 Peace & per305 Political authority \\
\hline per107 Internationalism: positive & per401 Free market economy \\
\hline per202 Democracy & per402 Incentives: positive \\
\hline per403 Market regulation & per407 Protectionism: negative \\
\hline per404 Economic planning & per414 Economic orthodoxy \\
\hline per406 Protectionism: positive & per505 Welfare limitation \\
\hline per412 Controlled economy & per601 National way of life: positive \\
\hline per413 Nationalisation & per603 Traditional morality: positive \\
\hline per504 Welfare expansion & \\
\hline
\end{tabular}




\begin{tabular}{|l|c|}
\hline per506 Education expansion & per605 Law and order: positive \\
\hline per701 Labour groups: positive & per606 Civic mindedness: positive \\
\hline
\end{tabular}

\section{Creation of the aggregate socio-economic dimension}

\begin{tabular}{|l|r|}
\hline Left-wing socio-economic policy cluster & Right-wing socio-economic policy cluster \\
\hline per110 European Community/Union: negative & per108 European Community/Union: positive \\
\hline per403 Market regulation & per401 Free market economy \\
\hline per404 Economic planning & per407 Protectionism: negative \\
\hline per405 Corporatism/mixed economy & per414 Economic orthodoxy \\
\hline per406 Protectionism: positive & per505 Welfare limitation \\
\hline per409 Keynesian demand management & per702 Labour groups: negative \\
\hline per412 Controlled economy & \\
\hline per413 Nationalisation & \\
\hline per415 Marxist analysis: positive & \\
\hline per416 Anti-growth economy and sustainability & \\
\hline per504 Welfare expansion & \\
\hline per506 Education expansion & \\
\hline per701 Labour groups: positive & \\
\hline
\end{tabular}

\section{Creation of the economic sub-dimensions}

\begin{tabular}{|l|r|}
\hline Left-wing economic policy sub-cluster & Right-wing economic policy sub-cluster \\
\hline per403 Market regulation & per401 Free market economy \\
\hline per404 Economic planning & per402 Incentives: positive \\
\hline per405 Corporatism/mixed economy & per407 Protectionism: negative \\
\hline per406 Protectionism: positive & per414 Economic orthodoxy \\
\hline
\end{tabular}




\begin{tabular}{|l|r|}
\hline per409 Keynesian demand management & \\
\hline per412 Controlled economy & \\
\hline per413 Nationalisation & \\
\hline per415 Marxist analysis: positive & Welfare limitation policy sub-cluster \\
\hline per416 Anti-growth economy and sustainability & per505 Welfare limitation \\
\hline Welfare expansion policy sub-cluster & per507 Education: limitation \\
\hline per504 Welfare expansion & per702 Labour groups: negative \\
\hline per506 Education expansion & per704 Middle class and professional groups \\
\hline per701 Labour groups: positive & \\
\hline
\end{tabular}

\section{Creation of the aggregate socio-cultural dimension}

\begin{tabular}{|l|r|}
\hline Left-wing socio-cultural policy cluster & Right-wing socio-cultural policy cluster \\
\hline per105 Military: negative & per104 Military: positive \\
\hline per107 Internationalism: positive & Per601 National way of life: positive \\
\hline per201 Freedom and human rights & per603 Traditional morality: positive \\
\hline per501 Environmental protection & per605 Law and order \\
\hline per503 Equality positive & per608 Multiculturalism: negative \\
\hline per602 National way of life: negative & \\
\hline per604 Traditional morality: negative & \\
\hline per607 Multiculturalism: positive & \\
\hline per705 Unprivileged minority groups & \\
\hline
\end{tabular}


Creation of the European integration dimension

Anti-European policies

Pro-European policies

per110 European Community/Union: negative

per108 European Community/Union: positive 


\section{Figures}

Figure 1.The salience of the anti-Memorandum issue by SYRIZA and ANEL

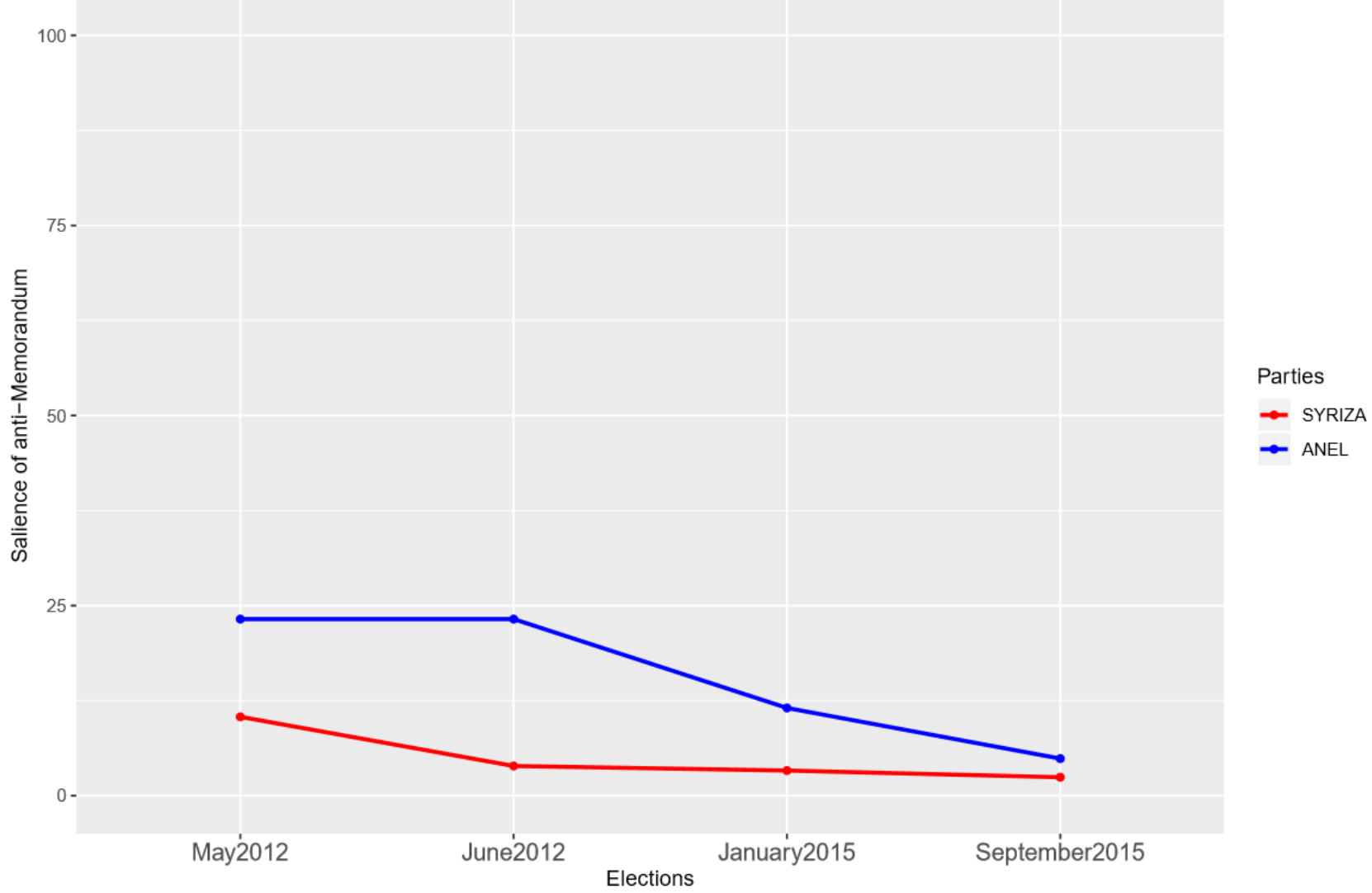

Figure 2. The positions of SYRIZA and ANEL on the Left/Right dimension

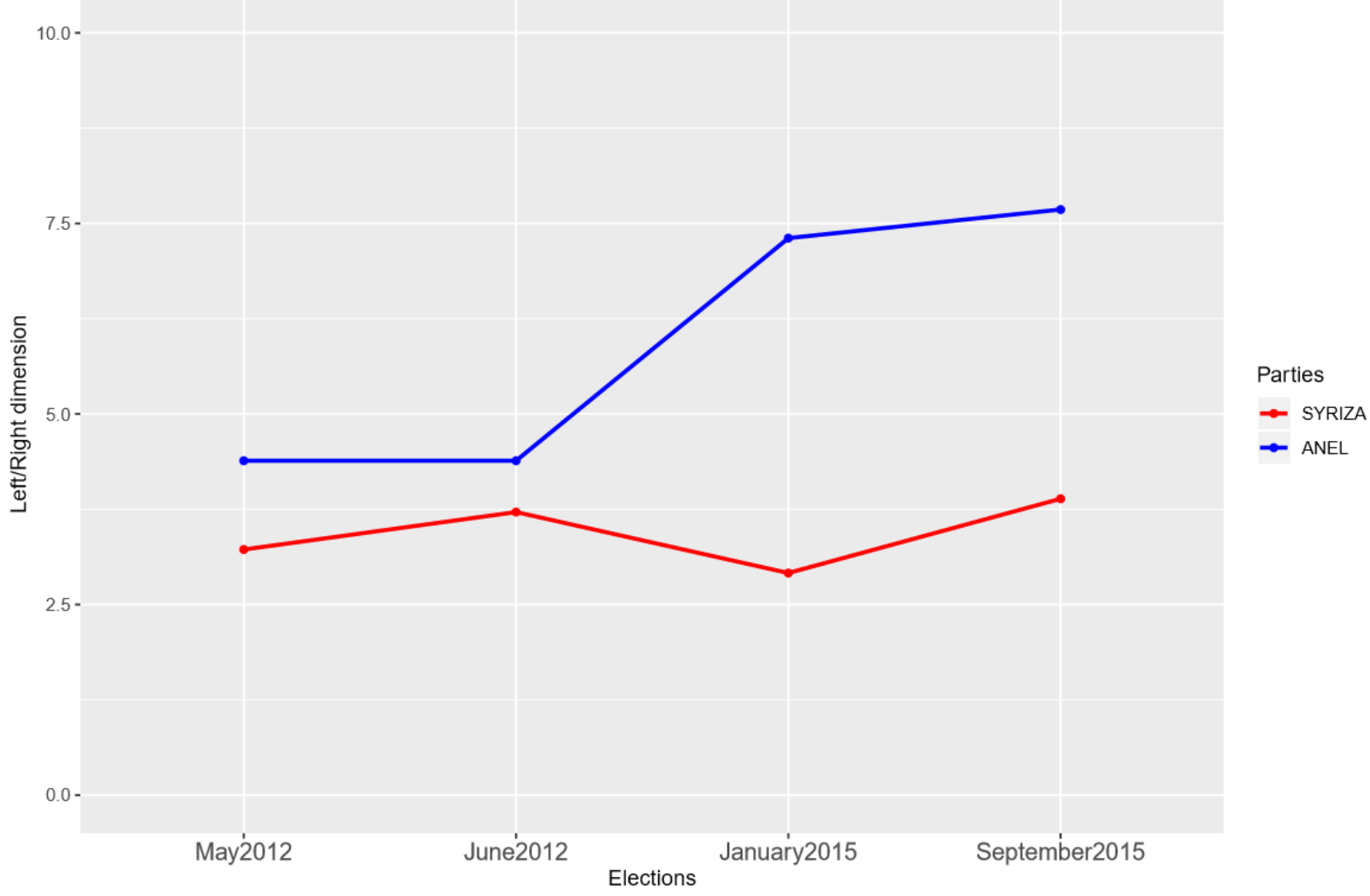


Figure 3. The positions of SYRIZA and ANEL on the socio-economic dimension

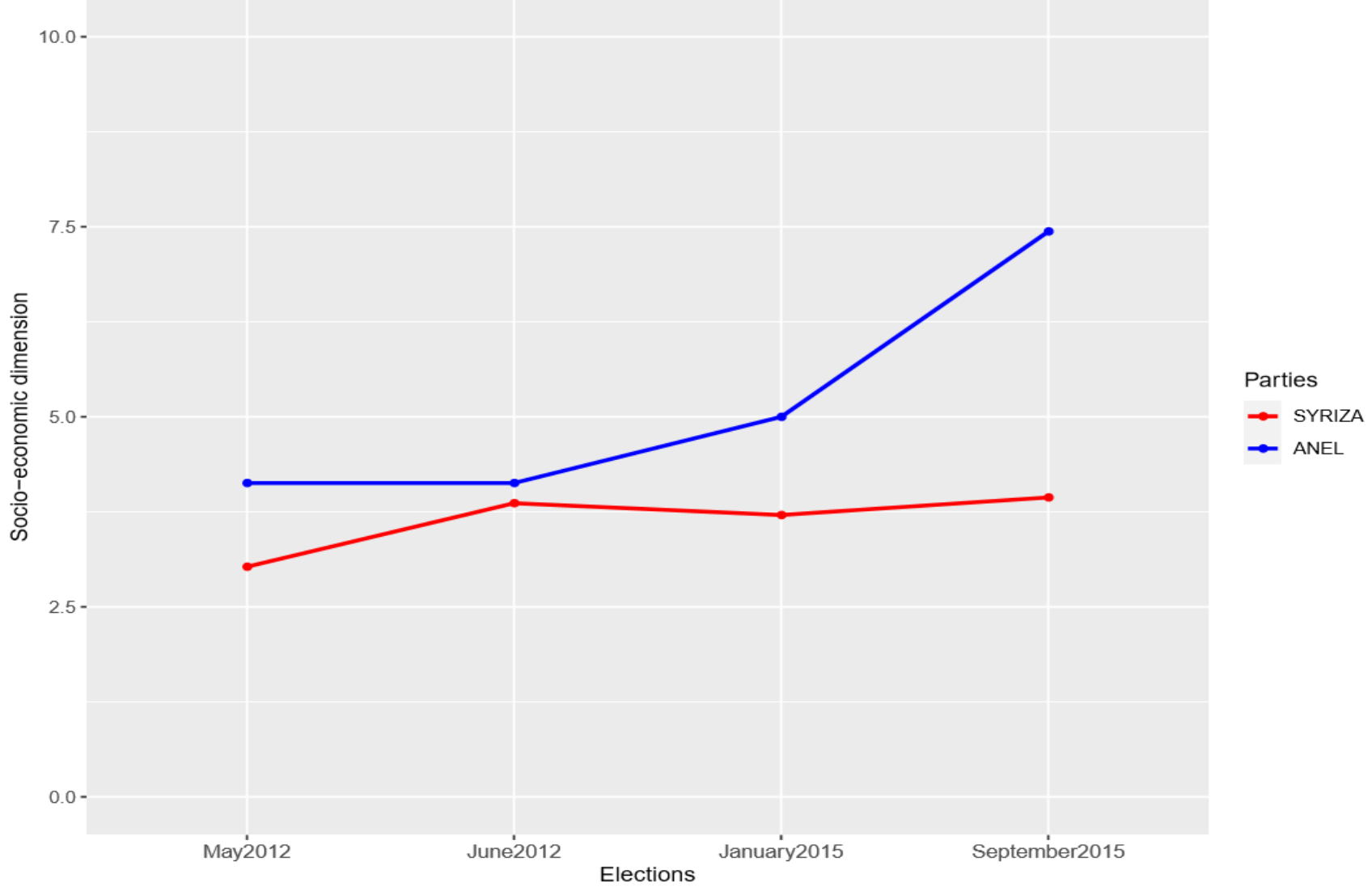

Figure 4. The positions of the League and the Five Star Movement on the Left/Right and socio-economic dimension

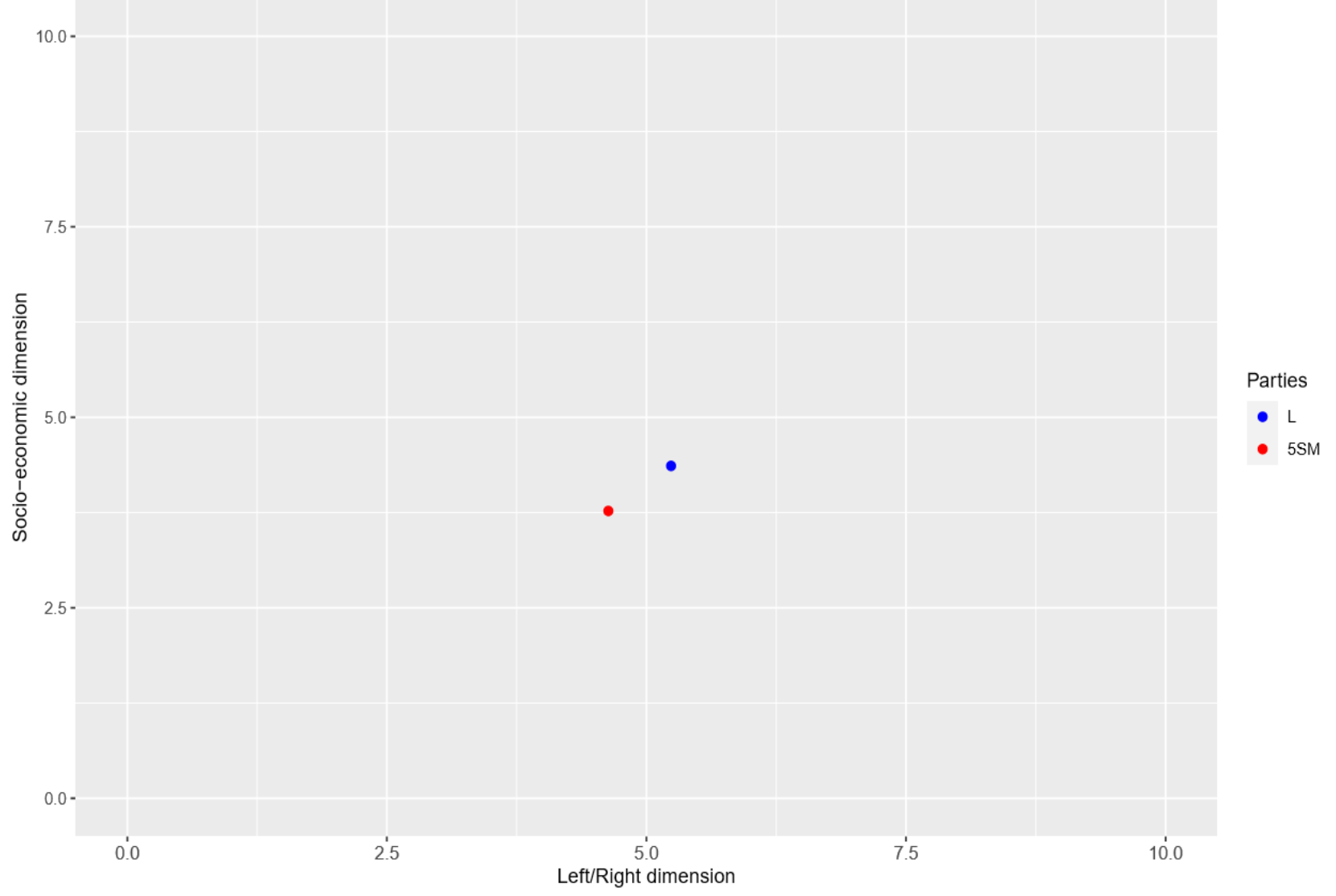


Figure 5.1 The positions of SYRIZA and ANEL on the economic sub-dimensions

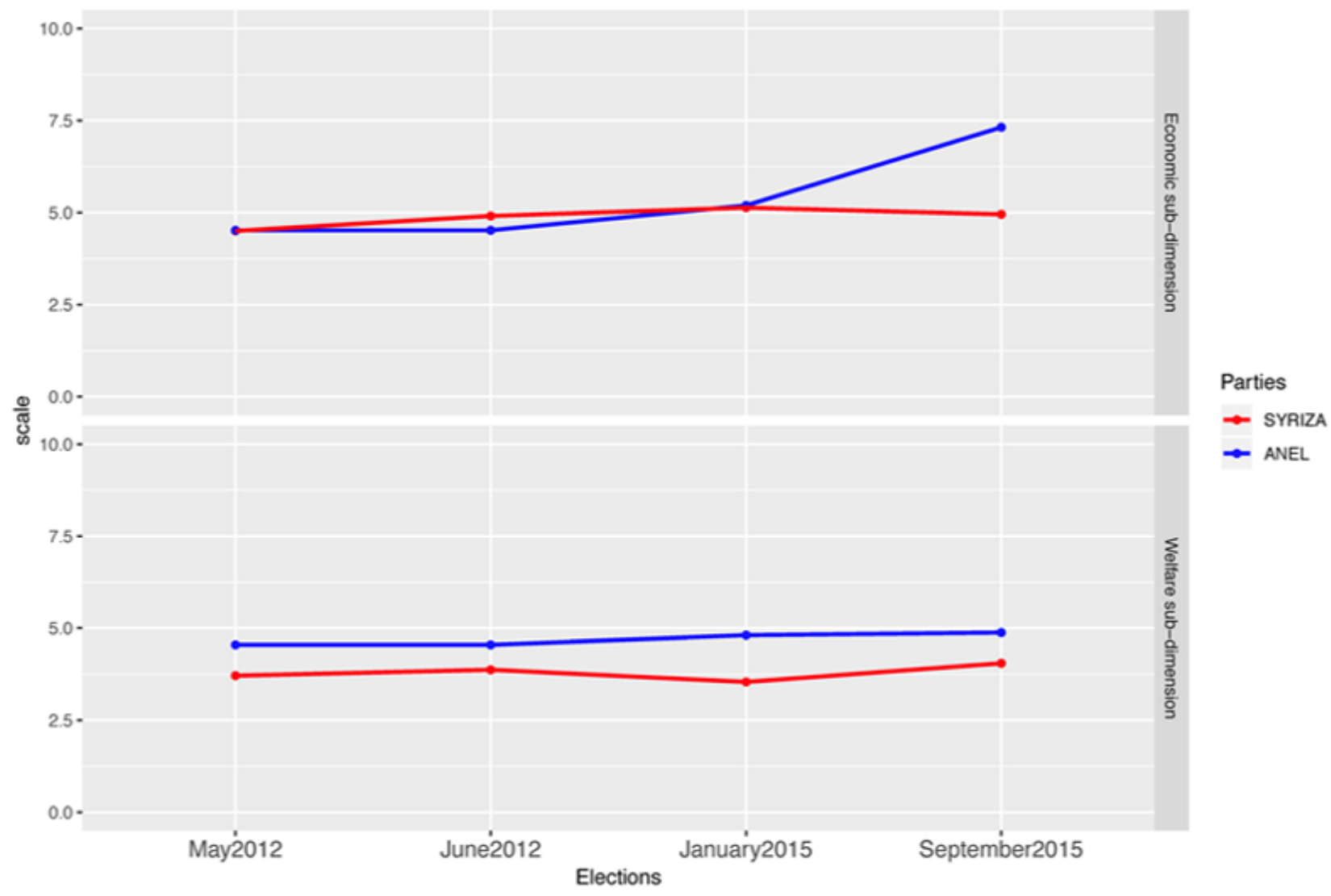

Figure 5.2. The positions of the League and the Five Star Movement on the economic sub-dimensions

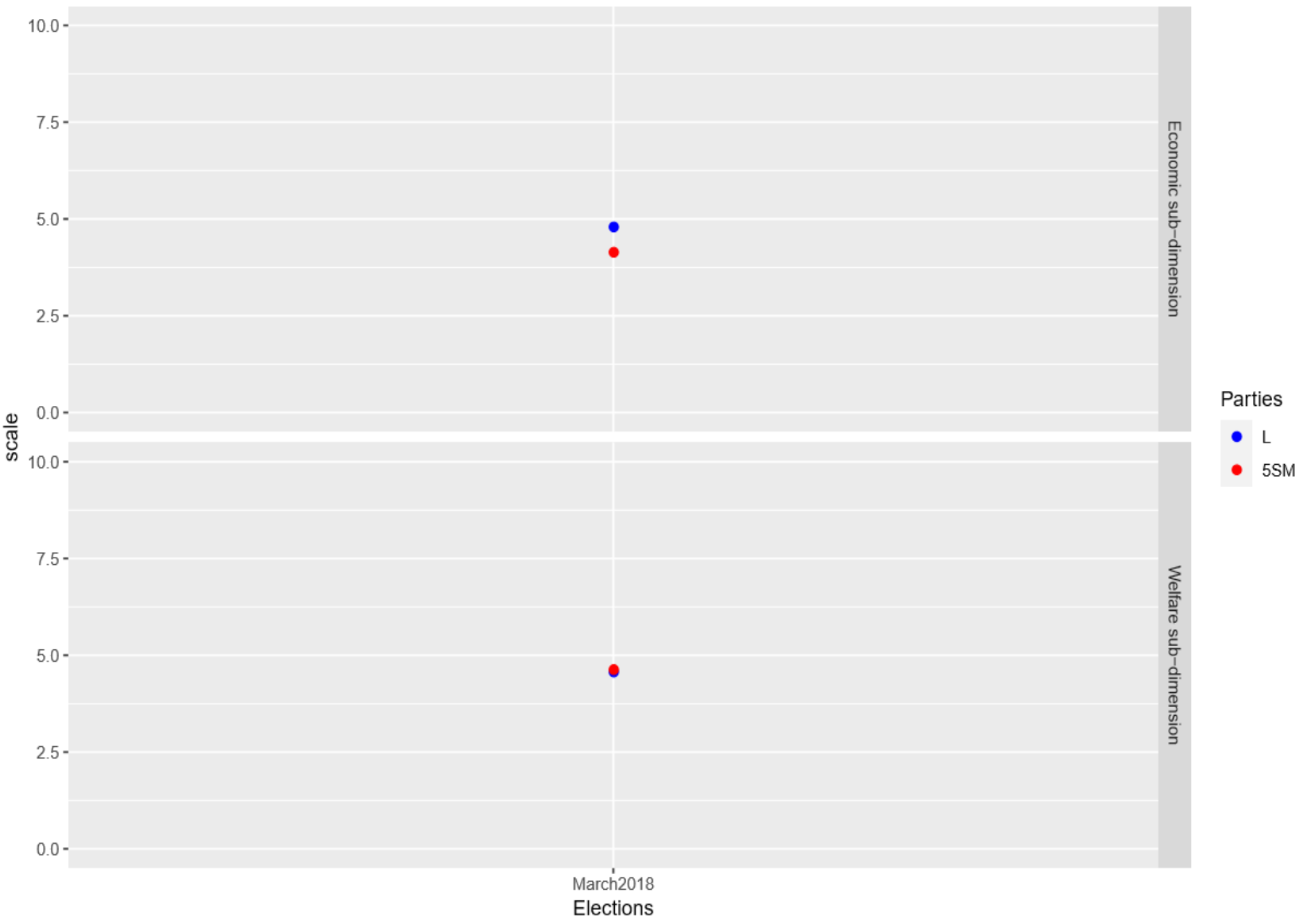


Figure 6. The positions of SYRIZA and ANEL on the socio-cultural dimension

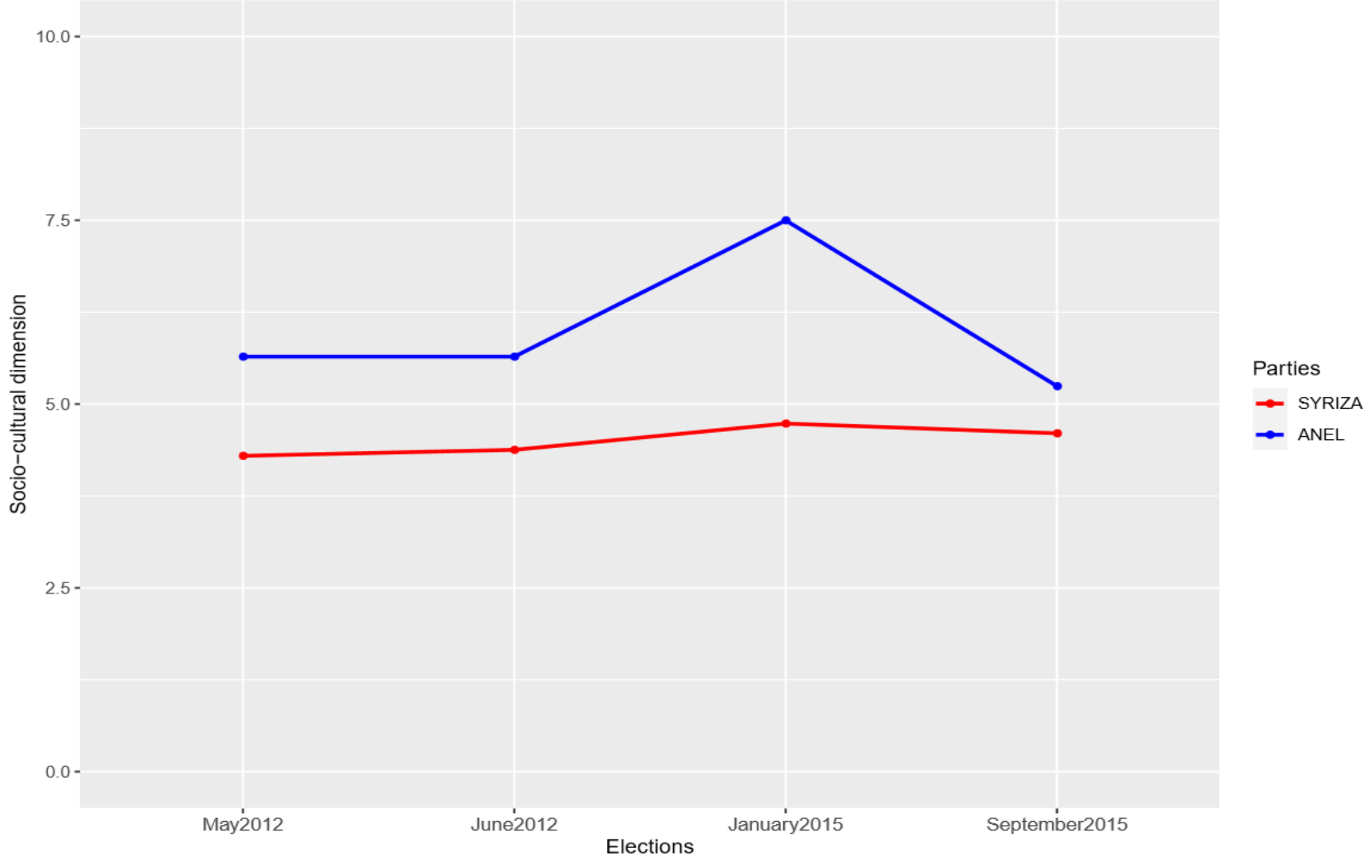

Figure 7. The positions of the League and the Five Star Movement on European integration and socio-cultural dimension dimension

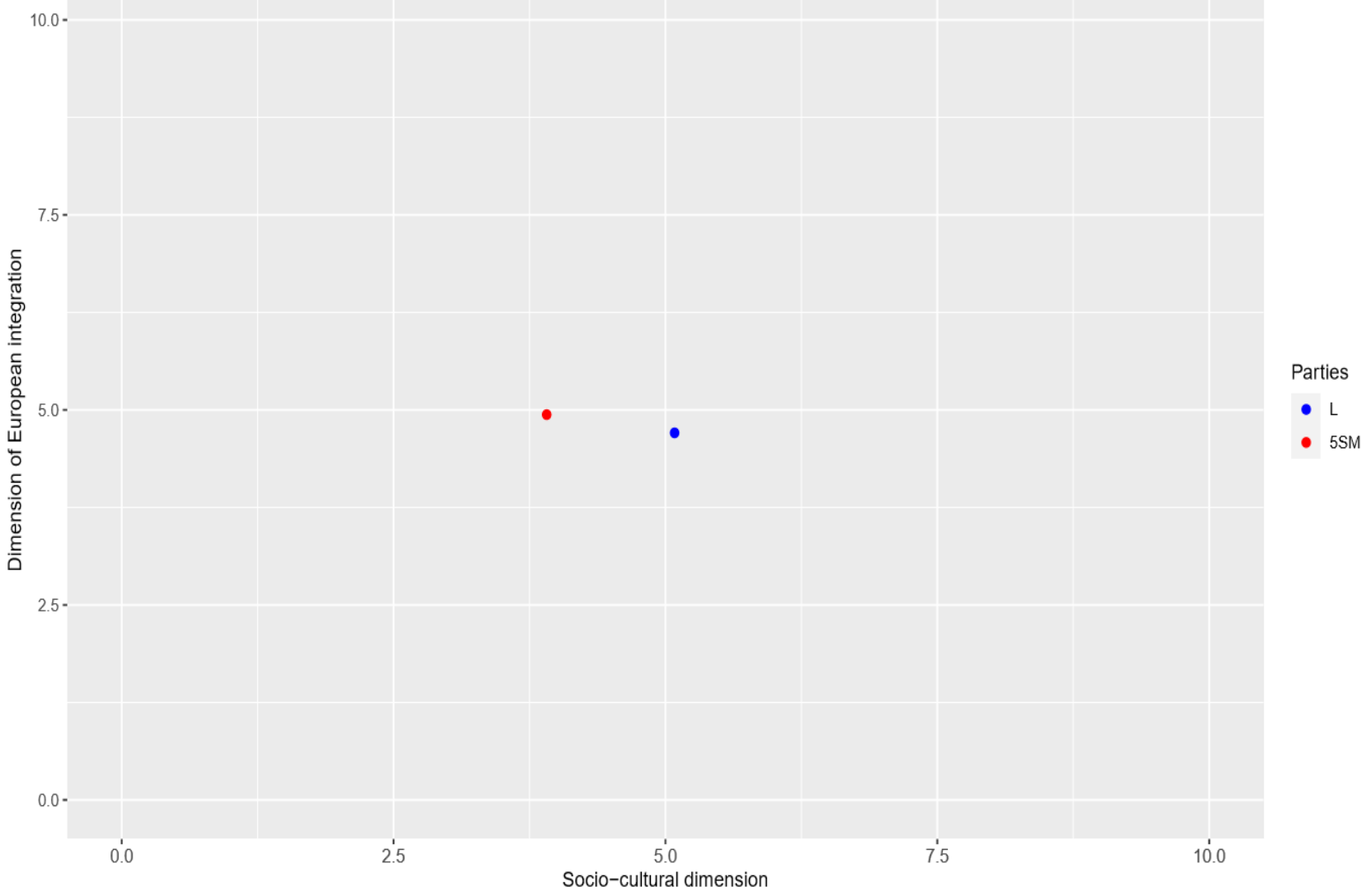

